\title{
Hubungan Antara Pola Makan Dan Status Gizi Dengan Tingkat Kebugaran Atlet Dayung
}

\author{
Rhildan Rahman Muharama ${ }^{\text {a }}$ Imas Damayanti ${ }^{\mathrm{b}}$, Yati Ruhayatic \\ ${ }^{a}$ Pendidikan Kesehatan dan Rekreasi, Universitas Pendidikan Indonesia, Bandung, Indonesia; ${ }^{b}$ Pendidikan Kesehatan dan \\ Rekreasi, ${ }^{c}$ Universitas Pendidikan Indonesia, Bandung, Indonesia.
}

Corresponding author: rildanrm@gmail.com

\begin{tabular}{l} 
A R T I C L E I N F O \\
\hline Article history: \\
Received 24 Maret 2019 \\
Received in revised form 09 \\
April 2019 \\
Accepted 24 April 2019 \\
Keywords: Relationship, Diet, \\
Nutritional Status, Level of \\
Physical Fitness Athlete \\
Rowing
\end{tabular}

\section{A R T I CLE INFO}

ticle history:

Received 24 Maret 2019

Received in revised form 09

April 2019

Keywords: Relationship, Diet, Physical Fitness Athlete Rowing

\begin{abstract}
A B S T R A C T
The purpose of this study is to obtain a broader picture of the relationship between diet and nutritional status with the level of physical fitness of rowing athletes in western district regency. The method used by quantitative descriptive method, the participants involved in this research are rowing athletes of west bandung regency, X1 dietary food diet $2 \times 24$ hours, X2 nutritional status calculation of body mass index (imt) and Y level of cooper test, with correlation and test contribution using regression test. The results of the first hypothesis test shows the value of X1 counts of $0.174>(0.05)(10)$. The result of the second hypothesis X2 test shows the value of 0.603> (0.05) (10), it can be concluded there is no significant relationship between diet and nutritional status with physical fitness level athletes paddle west bandung regency. Based on the results of regression analysis $\mathrm{X} 1$ contribution $\mathrm{X} 2 \& \mathrm{Y}$ obtained value $\mathrm{R}=0.476$, with $\mathrm{R}$ square value of 0.227 it can be concluded that Ho accepted. This shows there is no significant relationship between diet and nutritional status with fitness level. While the value of $\mathrm{R}$ square addressed the percentage of values that consider the effect of $\mathrm{X}$ to $\mathrm{Y}$ of $22.7 \%$, while the rest of $73.3 \%$ influenced by other factors. Can be concluded there is no relationship between diet and nutritional status with the level of physical fitness athletes rowing district west bandung.
\end{abstract}

\section{Pendahuluan}

Perkembangan olahraga dayung di Indonesia dari tahun ke tahun semakin berkembang dan menunjukkan perkembangan yang terus meningkat. Salah satu indikatornya adalah peningkatan prestasi atlet dayung yang mengikuti kejuaraan, kejuaraan baik tingkat nasional maupun internasional. Hal ini terbukti dengan adanya peningkatan baik kualitas maupun kuantitas dari peserta yang mengikuti kejuaraan yang diselenggarakan oleh Pengcab, Pengda, dan PB PODSI cabang olahraga dayung yang berkembang di indonesia merupakan gabungan dari tiga induk cabang olahraga, yaitu Rowing, Canoeing, dan Traditional Boat Race. Dayung merupakan salah satu jenis cabang olahraga aerobic (Daya Tahan) air sebagai sarana utamanya, serta perahu dan dayungan sebagai medianya. Cabang olahraga dayung sendiri ada yang bersifat permainan ada pula yang bersifat, perlombaan (PODSI, 1977).

Pada kompetisi Atlet nasional ataupun kompetisi olahraga lainnya, atlet akan membutuhkan jumlah asupan energi (kalori) yang besar untuk mendukung aktivitasnya. Dalam hal pemenuhan kebutuhan energi, seorang atlet secara umum disarankan untuk memenuhi kebutuhannya dengan 55-65\% melalui konsumsi karbohidrat, 20-35\% lemak serta $12-15 \%$ protein (Guyton., 1971). Dalam pengaturan pola makan untuk atlet aerobic seperti dayung energi yang diperlukan 
tubuh harus sesuai dengan kebutuhan. (F.D., 1994). Kebutuhan energi pada saat berolahraga dapat dipenuhi melalui sumber-sumber energi yang tersimpan di dalam tubuh yaitu melalui pembakaran karbohidrat, pembakaran lemak, serta kontribusi sekitar 5\% melalui pemecahan protein. Diantara ketiganya, simpanan protein bukanlah merupakan sumber energi yang langsung dapat digunakan oleh tubuh dan protein baru akan terpakai jika simpanan karbohidrat ataupun lemak tidak lagi mampu untuk menghasilkan energi yang dibutuhkan oleh tubuh (Irawan, 2007).

Pola makan adalah suatu cara atau usaha dalam pengaturan jumlah dan jenis makanan dengan maksud tertentu, seperti mempertahankan kesehatan, status nutrisi, mencegah atau membantu kesembuhan penyakit Makanan merupakan kebutuhan pokok setiap manusia, namun untuk memelihara tubuh agar menjadi lebih sehat makanan harus memenuhi beberapa syarat yaitu. Membantu pemeliharaan tubuh, dapat menyediakan bahan untuk pertumbuhan tubuh (Supariasa, I. Dewa Nyoman, Bachyar Bakri, 2002). Setiap aktivitas tubuh membutuhkan asupan energi yang mencukupi, sehingga faktor makanan ini mendapatkan perhatian yang serius. Konsumsi makanan yang terprogram dan terkontrol dengan baik dapat mendukung meningkatkan tingkat kebugaran jasmani seseorang, oleh karena itu unsur-unsur gizi seperti karbohidrat, protein, lemak, vitamin, mineral dan air harus benar tersedia dalam tubuh dan mencukupi untuk beraktivitas (Persagi, 2009).

Selain dari pola makan yang baik, atlet membutuhkan tingkat kebugaran jasmani yang lebih baik untuk dapat membantu tercapainya prestasi olahraga yang tinggi, kebugaran jasmani yang cukup untuk bekerja dengan baik, sehingga dapat meningkatkan daya kerja dan produktivitas yang tinggi. Kebugaran itu dicapai melalui sebuah kombinasi dari latihan teratur dan kemampuan yang melekat pada seseorang. Kebugaran jasmani merupakan bagian dalam pemeliharaan kesehatan, semakin tinggi tingkat kebugaran jasmani seseorang, maka akan semakin baik tingkat kesehatannya (Sharkey, Brian J., Gaskill, 2013). Seorang atlet dayung meiliki dominan olahraga daya tahan kekuatan harus mencakup aspek kebugaran jasmani yang baik untuk mndukung performanya (PODSI, 1977).

Apabila zat gizi dalam mencukupi maka kesehatan dan kebugaran jasmani atlet tersebut dalam keadaa maksimal, Didalam makanan terdapat kandungan-kandungan yang akan memberikan dampak baik bagi tubuh. Pola makan dan status gizi sangat menentukan bagaimana gambaran kebugaran jasmani atlet. Maka dari itu, di perlukan penelitian untuk mengetahui hubungan antara pola makan dan status gizi dengan tingkat kebugaran atlet dayung.

\section{Metode Penelitian}

Metode penelitian yang digunakan metode deskriptif kuantitatif. Penelitian ini merupakan penelitian korelasional dengan menghubungkan variabel terikat dan bebas. Variabel terikat yaitu kebugaran jasmani, dan variabel bebas pola makan, serta status gizi.

\subsection{Subjek}

Sebanyak 10 orang atlet dayung putra kabupaten bandung barat berusia antara 16-23 tahun dengan berat badan antara 51-77 kilogram dengan indeks masa tubuh 18,7-26,2 $\mathrm{kg} / \mathrm{m}^{2}$ di ambil secara nonprobability sampling atau sampling jenuh (Sugiyono, 2013).

\subsection{Instrumen}

Pola Makan (Food Recall)

Metode recall 24 jam (single and reparted 24 hours recalls) untuk individu. Prinsip metode ini 24 jam adalah mencatat jenis dan jumlah bahan makanan yang dikonsumsi pada periode 24 jam yang lalu. Hal penting yang perlu diketahui adalah bahwa data yang diperoleh dari recall 24 jam cenderung lebih bersifat kualitatif. Oleh sebab itu. Untuk mendaptkan data kuantitatif, jumlah konsumsi makanan individu di tanyakan secara teliti denggan menggunakan alat URT (sendok gelas piring dll) atau ukuran lainya yang biasa 
digunakan sehari-hari (Persagi., 2009).

Tujuan dari wawancara recall 24 jam adalah untuk mendapatkan informasi rinci tentang semua makanan dan minuman yang dikonsumsi dalam 24 jam sebelum wawancara. Seorang pewawancara yang berpengalaman, idealnya ahli gizi, atau peneliti yang menggunakan metode food recall 24 jam ini harus mewawancarai sampel menggunakan standar yang menggabungkan probe sistematis untuk memperoleh daftar lengkap semua bahan makanan yang dikonsumsi dan penjelasan rinci tentang setiap makanan. Para peneliti terdahulu, wawancara recall dicatat pada bentuk yang mirip dengan yang digunakan untuk catatan diet dan kemudian disesuaikan dan dianalisis dengan mengacu pada nutrisi basis data konten yang diteliti. dapat diterima antara ketepatan perkiraan asupan gizi itu dapat diterima dan sumber daya yang tersedia untuk memperoleh dan memproses data. Satu hari catatan makanan atau satu kali recall 24 jam tidak cukup untuk ciri asupan diet biasa dan status gizi karena kebanyakan orang mengalami variabilitas seharihari dalam asupan makanan. Variabilitas seharihari mungkin lebih akurat di antara atlet dari pada di kalangan masyarakat umum karena atlet sering memvariasikan diet mereka dengan jadwal pelatihan dan kompetisi dalam populasi umum, jumlah hari yang di perlukan untuk memperkirakan asupan individual atau jangka panjang individu bervariasi dari nutrisi ke gizi.

FOOD RECALL 24 JAM

Nama :

Hari :

Umur :

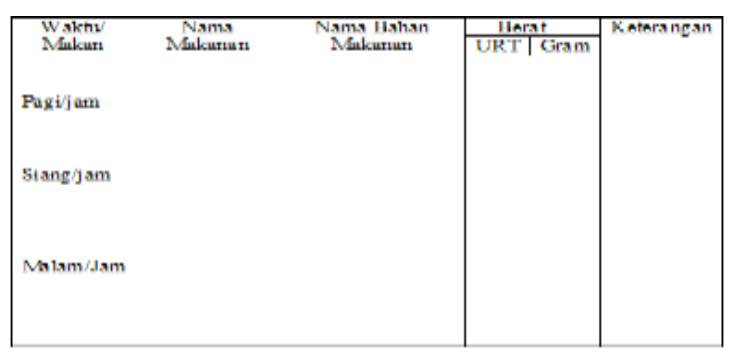

Gambar 1. Food Recall

\section{Status Gizi (IMT)}

Dalam status gizi diperoleh dengan mengukur tinggi badan dan berat badan kemudian dimasukkan ke dalam rumus Devenport-Koup, sehingga dari perhitungan tersebut akan didapatkan status gizi. Definsi Indeks massa tubuh (IMT) merupakan nilai yang diambil dari perhitungan hasil bagi antara berat badan (BB) dalam kilogram dengan kuadrat dari tinggi badan (TB) dalam meter. Hasil survey dibeberapa negara, menunjukan bahwa bahwa IMT ternyata merupakan suatu Indeks yang responsif, sensitif terhadap perubahan keadaan gizi, ketersediaan pangan menurut musim, dan produktivitas kerja. IMT dipercayai dapat menjadi indikator atau menggambarkan kadar adipositas dalam tubuh seseorang. Kemudian dikonversi dalam kelompok umur dengan standar deviasi yang telah ditetapkan sebagai norma penelitian. Indeks massa tubuh secara signifikan berhubungan dengan kadar lemak tubuh total sehingga dapat dengan mudah mewakili kadar lemak tubuh. Saat ini, IMT secara internasional diterima sebagai alat untuk mengidentifikasi kelebihan berat badan dan obesitas (James, Ferro-Luzzi, \& Waterlow, 1988).

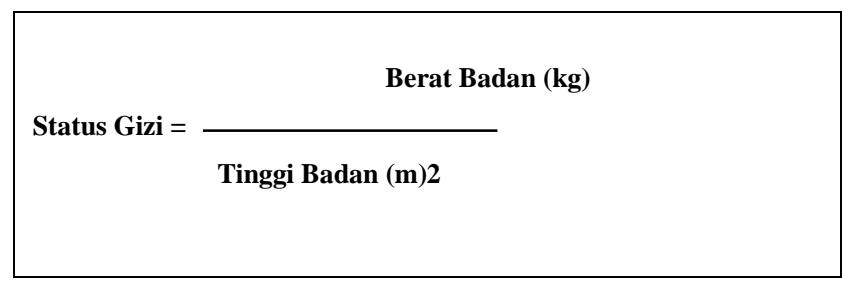

Gambar 2. Penghitungan Status Gizi IMT.

Tingkat kebugaran (cooper test)

Instrumen penelitian yang digunakan peneliti untuk mengukur tingkat kebugaran jasmani adalah alat ukur berupa tes kebugaran jasmani tes lari 12 menit atas dasar pertimbangan bahwa tes ini merupakan tes standar yang digunakan. Mengenai tes lari 12 menit ini tes ini pada dasarnya untuk mengukur kapasitas aerobik. Tes ini adalah suatu cara yang sangat baik untuk menentukan fitness seseorang (general fitness) dan kemampuan fisiknya. Hal ini sesuai dengan 
pendapat (Sharkey at al 2013). Tes lari jauh bertujuan untuk mengukur daya tahan jantung, peredaran darah dan pernafasan. Alasan mengapa peneliti menggunakan tes kebugaran jasmani dengan tes lari 12 menit dalam penelitian ini seperti yang diutarakan oleh (Pollock et al., 1976)

\subsection{Prosedur penelitian}

Prosedur penelitian pada penelitian ini diawali dengan melakukan studi lapangan yaitu menghubungi sampel yang akan dijadikan obyek penelitian lalu melaksanakan penelitian dengan menentukan sampel yang akan dijadikan sampel penelitian, menyusun dan menentukan instrumen penelitian. Setelah itu, sampel dilakukan food recalls selama $2 \times 24$ jam dengan mencatat apa saja yang telah di makan, dan status gizi dengan penimbangan \& tinggi badan untuk menhitung indeks masa tubuh. Lalu, dilakukan pengetesan tingkat kebugaran dengan tes cooper untuk melihat V02max atlet dayung, dengan prosedur lari selama 12 menit yang dilaksanakan di Stadion Pusdikav Padalarang

\subsection{Analisis Data}

Setelah semua data terkumpul, langkah selanjutnya adalah menganalisis data tersebut, untuk mengetahui ada tidaknya hubungan yang positif antara variabel independen dan variabel dependen, maka digunakan rumus Correlation product moment dari pearson dan analisis regresi berganda. Analisi data pada penelitian ini menggunakan jasa komputer seri SPSS 21

\section{Hasil dan Pembahasan}

Tabel 1. Data Deskriptif Pola Makan, Status Gizi, Tingkat Kebugaran

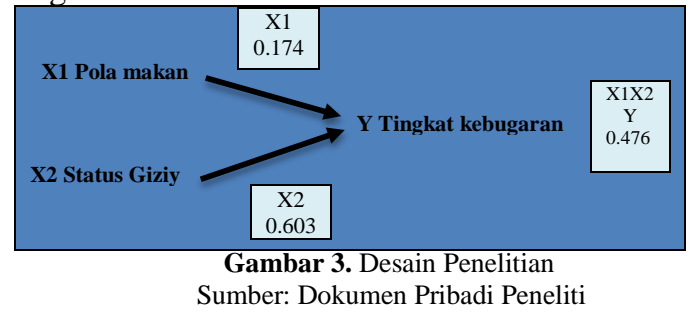

Hasil analisis korelasi status gizi dan tingkat kebugaran di atas menunjukkan nilai sebesar 0,603>0.05. Maka dengan demikian dapat diartikan bahwa tidak terdapat hubungan antara status gizi tingkat dengan kebugaran jasmani atlet dayung.

Tabel 2. Mutiple Regression

\begin{tabular}{lll}
\hline $\mathbf{N}$ & $\mathbf{R}$ & $\mathbf{R}$ square \\
\hline $\mathbf{1 0}$ & 0.47 & 0.227
\end{tabular}

Hasil tabel di atas dengan nilai regresion sebesar 0.227 maka dapat disimpulkan, hal ini menjukan tidak terdapat hubungan yang signifikan antara pola makan dan status gizi dengan tingkat kebugaraan, dengan nilai regresion menujukan presentase nilai yang menimbangkan pengaruh X1 dan X2 terhadap Y sebesar $22.7 \%$, sedangkan sisanya sebesar 73,3 \% dipengaruhi faktor lain.

Hasil food recall penelitian menunjukan bahwa 2 kali recall 24 jam tanpa berturut-turut, dapat menghasilkan gambaran asupan zat gizi lebih optimal dan memberikan variasi yang lebih besar tentang asupan harian individu (sanjur, 1997). Rata-rata makanan yang di konsumsi atlet kurang baik ditunjukan dengan nilai rata-rata $67.13 \%$. Akan tetapi, seharusnya makanan atltet memiliki nilai pola makan (Energi) $\geq 80 \%$ (Irawan, 2007). Asupan makan yang baik akan sangat berpengaruh terhadap kondisi dan kesehatan tubuh seseorang. Asupan makan yang baik bagi tubuh adalah dengan terpenuhinya zatzat yang diperlukan tubuh.

Apalagi untuk atlet yang Aktifitasnya tinggi dengan pola makan yang baik dan teratur, gizi menjadi seimbang, kondisi badan akan menjadi ideal dan kondisi fisik menjadi kuat, sehingga berpengaruh terhadap kebugaran jamani seseorang ( Brian et al, 2013). Sedangkan sumber energi itu sendiri diperoleh melalui makanan yang dapat berupa karbohidrat, protein, lemak, vitamin, mineral dan air. Fungsi pokok dari karbohidrat dan lemak tubuh adalah menyediakan energi bagi kerja sel. Ini termasuk kerja kontraktif serabut otot, oleh karenanya karbohidrat dan lemak 
merupakan sumber energi utama untuk olahraga (Irianto, 2007).

Pada jenis-jenis olahraga yang bersifat ketahanan (endurance), produksi energi didalam tubuh akan bergantung pada sistem metabolisme energi secara aerobic melalui pembakaran karbohidrat, lemak dan juga sedikit dari pemecahan protein (Benardot, 2012). Oleh karena itu, maka atlet dengan olahraga yang bersifat endurance harus mempunyai kemampuan baik dalam memasok oksigen dalam tubuh agar proses metabolisme energi secara aerobic dapat berjalan sempurna pada saat olahraga. Kedua simpanan energi di dalam tubuh disimpan dalam bentuk simpanan karbohidrat (glukosa darah, glikogen otot dan hati) serta simpanan lemak dalam bentuk trigliserida yang akan memberikan kontribusi terhadap laju produksi energi secara aerobic di dalam tubuh.

Status gizi merupakan ekspresi dari keadaan keseimbangan dalam bentuk variabel tertentu, atau perwujudan dalam bentuk variabel tertentu. Status gizi juga merupakan akibat dari keseimbangan antara konsumsi dan penyerapan zat gizi dan penggunaan.zat-zat gizi tersebut atau keadaan fisiologik akibat dari tersedianya zat gizi dalam seluruh tubuh. Dilihat dari penhitungan IMT (indeks massa tubuh) berdasrkan umur (DepKes, 1994). Rata-rata penghitungan IMT (indeks massa tubuh) atlet dayung masuk kategori normal dengan nilai rata-rata 21,32.

Asupan energi harus mendukung pelatihan atlet dan jadwal yang kompetitif agar memungkinkan atlet untuk mencapai tujuan latihan atlet. Memperkirakan kebutuhan energi sangatlah sulit dikarenakan variasi harian-kemusim yang signifikan dalam tingkat aktivitas, intensitas pelatihan, dll. Analisis satu atau lebih 23 hari catatan makanan dan berat badan stabil, yang mewakili keseimbangan antara intake dan output, dapat digunakan sebagai alat untuk menentukan kebutuhan energi atlet dan kecukupan asupan mereka. Meningkatkan asupan energi, atlet dapat meningkatkan ukuran porsi makanan dikonsumsi atau ditambah jumlah makanan sehari-hari dan camilan yang dikonsumsi. Membandingkan asupan nutrisi yang dilaporkan sebagai persentase (Wiita, B.G. 1996.).

Hasil dari tes cooper untuk melihat berapa tingkat kebugaran jasmani dilihat dari hasil Vo2max perindividu Atlet masuk ke kategori cukup baik untuk Atlet. (F.D., 1994). Kebugaran jasmani merupakan satu aspek dari kebugaran menyeluruh (total fitness).

Hasil penelitian yang dilakukan Sandrawaty (2016) kegiatan ekstrakurikuler olahraga hoki yang memberikan berbagai manfaat bagi perkembangan siswa dengan instrumen TKJI, yaitu salah satunya untuk meningkatkan kebugaran jasmani. Dari penjelasan penelitian tersebut dapat meningkatkan kebugaran jasmani pada olahraga hoki.

Dalam asupan pola makan kebutuhan karbohidrat untuk atlet selama menjalani latihan dengan waktu yang lama atau > 60 menit dengan intens pelatihan 65-70\% VO2 max membutuhkan 8-10 g karbohidrat $/ \mathrm{kg}$ berat badan/hari, sementara pelatihan untuk kurang dari 60 menit membutuhkan $5 \mathrm{~g}$ karbohidrat/kg berat badan/hari (Assessment \& Intake, 1995). Minimal konsumsi 200 g karbohidrat/hari dianjurkan untuk menjaga stamina dan glikogen hati untuk memenuhi kebutuhan energi selama beraktivitas. Glikogen di dalam otot yang cukup penting untuk kinerja ketahanan optimal dan adaptasi pelatihan karena perannya sebagai penyedia utama energi. Dengan demikian, asupan karbohidrat yang tidak mencukupi dapat menyebabkan kelelahan glikogen otot selama latihan yang berulang-ulang dari pelatihan intensif.

Pada prinsipnya setiap orang harus menyediakan energi makanan yang memadai untuk mempertahankan keseimbangan kalori. Keseimbangan kalori mengacu pada suatu keadaan dimana jumlah kalori yang diberikan dalam makanan benar-benar seimbang dengan kalori yang dikeluarkan melalui berbagai macam aktivitas. Faktor-faktor yang mempengaruhi 
sumber energi selama beraktivitas diantaranya intensitas aktivitas yang dilakukan dan lamanya waktu beraktivitas. Kedua faktor tersebut akan mempengaruhi kemampuan seseorang dalam melakukan aktvitas, karena setiap aktivitas membutuhkan energi (Brian et al 2013).

Energi yang dimakan masih belum terpenuhi dengan baik, dan masih sering mengonsumsi makanan instan yang kurang menunjang gizi, karena kebutuahan ernergi atlet harus di atas 2300kkl (Irawan, 2007). Meningkatkan perencanaan dan pengelolaan atlet yang terlatih dengan baik langkah yang ditargetkan, tidak diragukan lagi sangat penting untuk asupan gizi atau nutrisi dari berbagai kelompok atlet. Pola makan atlet untuk kompetisi besar harus dipastikan pengawasan. Hanya dengan nutrisi yang cukup atlet bisa menjaga tubuh mengkompensasi peningkatan energi dan nutrisi kebutuhan dan dengan demikian memudahkan adaptasi maksimal beban fisik atlet. Atlet harus punya ketahan agar dapat meningkatkan kapasitas aerobik mereka untuk diatasibeban fisik sehari-hari dan dapat daya tahan lama dengan baik. Performa fisik dan kelelahan yang dialami atlet. Selama latihan aerobik sebagian bergantung pada endogen cadangan karbohidrat terakumulasi dalam tubuh dan ketersediaan karbohidrat eksogen selama beban fisik. Karena itu, saat bertahan 2-3 jam intens beban fisik Setiap hari, atlet harus mengkonsumsi yang dianjurkan jumlah karbohidrat (7-12 g / kg berat badan) Sedangkan asupan protein yang di rekomendasikan adalah 1,2-1,6 g / kgdari berat badan, dan nilai energi yang dipasok oleh lemak seharusnya tidak lebih tinggi dari $35 \%$. Selain itu, atlet harus mengkonsumsi di rekomendasikan jumlah vitamin dan mineral.

Zalcman et al (2007) meneliti dengan mendeskripsikan asupan makanan yang biasa, komposisi tubuh, dan profil biokimia pembalap petualangan selama musim pelatihan mereka dan mengevaluasi asupan energi dan nutrisi mereka dalam kaitannya dengan rekomendasi saat ini untuk atlet olahraga ultra. Metode: Dua puluh empat atlet balap petualangan (18 pria dan 6 wanita), 24 hingga 42 tahun, berpartisipasi dalam penelitian ini. Asupan makanan ditentukan dengan catatan makanan 3-d dan komposisi tubuh oleh plethysmography. Sampel darah diperoleh dari semua subyek untuk analisis biokimia. Semua penilaian dilakukan selama fase pelatihan biasa Atlet wanita memiliki persentase lemak tubuh yang lebih tinggi daripada atlet laki-lak (20,2 $5,7 \%$ dibandingkan $12,53,5 \%$ ). Untuk pria dan wanita, asupan makanan tinggi protein $(1,90,5 \mathrm{~g} /$ $\mathrm{kg}$ pada pria, 2,0 0,4 g / kg pada wanita) dan lemak (1,6 0,3 g / kg pada pria, 1,5 1,3 g / kg pada wanita). Asupan karbohidrat atlet laki-laki berada di batas bawah yang direkomendasikan $(5,9$ ? 1,8 $\mathrm{g} / \mathrm{kg}$ ). Untuk sebagian besar vitamin dan mineral, asupan atlet cukup, dengan pengecualian magnesium, seng, dan kalium pada pria dan wanita serta vitamin E dan kalsium pada wanita, yang menunjukkan kemungkinan tinggi tidak adekuat dibandingkan dengan nilai referensi. Tingkat kolesterol total dan kolesterol low-density lipoprotein dalam darah tinggi ditemukan pada atlet wanita (masing-masing 201.0, 44,7 dan 104,1 ? 43,1 mg / dL) dan semua analisis biokimia lainnya berada dalam nilai referensi normal. Atlet Pembalap petualangan menyajikan profil nutrisi yang tidak memadai bila dibandingkan dengan rekomendasi untuk latihan ketahanan. Atlet-atlet ini perlu dididik tentang mengkonsumsi makanan yang cukup untuk memenuhi kebutuhan nutrisi dari aktivitas mereka.

\section{Simpulan dan Rekomendasi}

Berdasarkan hasil analisis data di atas, maka. tidak terdapat hubungan yang signifikan antara pola makan dan status gizi dengan tingkat kebugaran jasmani Atlet Dayung Daerah Kabupaten Bandung Barat. Penelitian ini diperkuat berdasarkan hasil uji korelasi dan regresi $\mathrm{R}=$ 0.476 , dengan nilai $\mathrm{R}$ square sebesar 0.227 maka dapat disimpulkan bahwa Ho diterima. Atlet yang mepunyai kebugaran jasmani kurang untuk dapat 
ditingkatkan dengan menjaga pola makan dan status gizi.

\section{Daftar Pustaka}

Assessment, A., \& Intake, C. (1995). An Assessment of Carbohydrate Intake, 206214.

Baranauskas, M., Stukas, R., Tubelis, L., Žagminas, K., Šurkiene, G., Švedas, E., ... Abaravičius, J. A. (2015). Nutritional habits among high-performance endurance athletes. Medicina (Lithuania), 51(6), 351-362.

Benardot, D. (2012). Advanced Sports Nutrition, 424. Retrieved

DepKes, R. I. (1994). Pedoman Sanitasi Rumah Sakit di Indonesia. Direktorat Jenderal P2M \& PLP Dan Direktorat Jenderal Pelayanan Medik, Jakarta.

F.D., W. (1994). Health services utilization among older adults: Conceptual, measurement, and modeling issues in secondary analysis. Gerontologist, 34(4) 470-475. Retrieved

Irawan, M. A. (2007). Nutrisi, Energi, \& Performa olahraga. Polton Sport Science \& Performance Lab, 1, 1-13.

Irianto, D. P. (2002). "Pedoman praktis berolahraga untuk kebugaran dan kesehatan.” Yogyakarta: Andi Offset.

Irianto, D. P. (2007). "Panduan gizi lengkap keluarga dan olahragawan." Yogyakarta; Andi Offset.
James, W. P. T., Ferro-Luzzi, A., \& Waterlow, J. C. (1988). Definition of Chronic Deficiency in Adults - Report of a Working Party of the International Dietary Energy Consultative Group. European Journal of Clinical Nutrition, 42(12), 969-981.

Pollock, M. L., Bohannon, R. L., Cooper, K. H., Ayres, J. J., Ward, A., White, S. R., \& Linnerud, A. C. (1976). A comparative analysis of four protocols for maximal treadmill stress testing. American Heart Journal, 92(1), 39-46.

Sandrawaty, M. (2016). PENGARUH PEMBELAJARAN PERMAINAN HOKI KEPERCAYAAN DIRI SISWA DI SMA NEGERI 26 GARUT. Jurnal Terapan Ilmu Keolahragaan, 1(2), 59-63.

Sharkey, Brian J., Gaskill, S. (2013). Fitness \& Health 7th Edition.

Sugiyono, M. P. K. (2013). Kualitatif, dan Kombinasi (Mixed methods). Bandung: Alfabeta.

Supariasa, I. Dewa Nyoman, Bachyar Bakri, and I. F. (2002). Penilian Status Gizi. Jakarta: EGC.

Wiita, B.G. and Stombaugh, I. . (n.d.). Nutrition knowledge, eating practices and Runners, health of adolescent femalea 3-year longitudinal study. Int. J. Sport.

Zalcman,I., S, M, Guarita, H. V., D. R., Juzwiak, C. R., Ph, D., (2007). Nutrional Status of Adventure Racers, 23, 404-411. 